\title{
The First Newborn Case of Coronavirus Disease 2019 (COVID-19) in Turkey
}

\author{
Türkiye'den IIlk Yenidoğan Koronavirüs Hastalığı 2019 (COVID-19) Vakası
}

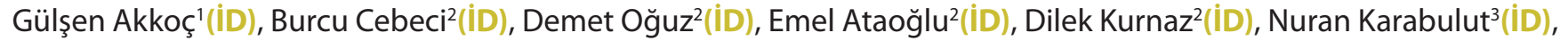 \\ Derya Büyükkayhan²(ID) \\ ${ }^{1}$ Clinic of Pediatric, Istanbul Haseki Training and Research Hospital, Istanbul, Turkey \\ ${ }^{2}$ Clinic of Neonatal, Istanbul Haseki Training and Research Hospital, istanbul, Turkey \\ ${ }^{3}$ Clinic of Medical Microbiology, İstanbul Haseki Training and Research Hospital, İstanbul, Turkey
}

Cite this article as: Akkoç G, Cebeci B, Oğuz D, Ataoğlu E, Kurnaz D, Karabulut N et al. The first newborn case of coronavirus disease 2019 (COVID-19) in Turkey. J Pediatr Inf 2021;15(2):e109-e111.

\section{Abstract}

Newborn cases commonly have milder COVID-19 disease. However, this is not enough to define knowledge about clinical manifestation and prognosis of this disease in newborns. A 17-day-old male neonate was admitted to the emergency room with fever and refusal to breastfeed at March 12, 2020. His pharyngeal swab testing was positive with real-time reverse transcription polymerase chain reaction ( $r R T-P C R$ ) assay for SARS-CoV-2. Except his father, all his close contacts were asymptomatic and screened for SARS-CoV-2 and all his close contacts have revealed as positive. During this very contagious outbreak, the COVID-19 disease should be considered in newborns with fever or refusal of feeding.

Keywords: Newborn, severe acute respiratory syndrome coronavirus-2, coronavirus disease-2019

\section{Introduction}

In December 2019, the novel coronavirus severe acute respiratory syndrome coronavirus-2 (SARS-CoV-2) caused a life-threatening respiratory disease called COVID-19 firstly in Wuhan, China (1). This disease has rapidly spread worldwide. At the beginning of the outbreak, this disease was seen in
Öz

Yenidoğan vakalarında genellikle COVID-19 daha hafif seyirlidir. Ancak bu, yenidoğanlarda bu hastalığın klinik görünümü ve prognozu hakkındaki bilgileri tanımlamak için yeterli değildir. On yedi günlük erkek yenidoğan ateş ve emzirmeyi reddetme şikayetiyle acil servise başvurdu. Nazofarengeal sürüntü örneği, SARS-CoV-2 için gerçek zamanlı ters transkripsiyon polimeraz zincir reaksiyonu (rRT-PCR) testiyle pozitif saptandı. Babası dışında, tüm yakın temasları asemptomatikti ve SARSCoV-2 pozitif saptandı. Bu çok bulaşıcı salgın sırasında, ateşli veya beslenmeyi reddeden yenidoğanlarda COVID-19 hastalığı düşünülmelidir.

Anahtar Kelimeler: Yenidoğan, ağır akut solunum sendromu koranavirüs-2, koronavirüs hastalığı 2019

adult cases; with the increase in the number of cases, pediatric cases started to appear (1,2). Despite a large number of patients being diagnosed with COVID-19 disease, the rate of child cases varies between $1-2 \%$ in different countries $(2,3)$. It is observed that COVID-19 has a milder and less severe course in pediatric cases. There are a few reports of newborns with COVID-19 (4,5). These newborn cases commonly have milder

\footnotetext{
Correspondence Address / Yazışma Adresi

Gülşen Akkoç

İstanbul Haseki Eğitim ve Araştırma Hastanesi,

Çocuk Sağlığı ve Hastalıkları Kliniği,

İstanbul-Türkiye

E-mail: agulsenakkoc@gmail.com
} 
COVID-19 disease (6). But this is not enough to define knowledge about clinical manifestation and prognosis of this disease in newborns.

Herein, we report a case of a 17-day-old male newborn with neonatal COVID-19 disease confirmed using pharyngeal swab testing positive with real-time reverse transcription polymerase chain reaction (rRT-PCR) assay for SARS-CoV-2.

\section{Case Report}

The 17-day-old full-term neonate was admitted to the emergency room with fever and refusal to breastfeed March 12,2020 . At the admission, the patient had fever $38^{\circ} \mathrm{C}$, was alert, and his physical examination was completely normal. He had no hospitalization history. He was the first child of nonconsanguineous parents, born by cesarean delivery with a birth weight of $4000 \mathrm{~g}$. The mother had a good prenatal follow-up, and during the pregnancy, she got vitamins, iron, and Omega-3 supplement. His father was a cabin crew member and recently had traveled abroad. His father had suffered mild weakness for two days but had no fever and cough. Laboratory analysis results of the child were as follows: hemoglobin: $14.5 \mathrm{~g} / \mathrm{dl}$, white blood cell count: $7.88 \times 10^{9} / \mathrm{L}$, lymphocyte count: $3.40 \times 10^{9} / \mathrm{L}$, neutrophil count: $1.96 \times 10^{9} / \mathrm{L}$, platelet count: $260 \times 10^{3} / \mathrm{L}$, and C-reactive protein: $1.8 \mathrm{mg} / \mathrm{L}(0-5)$. Liver transaminases were within normal ranges. Urine sediment $\mathrm{mi}-$ croscopic examination showed 8 leucocytes $/ \mathrm{mm}^{3}$. Influenza $A / B$ and respiratory syncytial virus antigen tests were negative. He was hospitalized in the neonatal intensive care unit. A pharyngeal swab was performed for SARS-CoV-2 testing rRTPCR assay from him and his father. Blood and urine cultures were obtained. Ampicillin and amikacin were started. His posterior-anterior chest radiography, cranial and abdominal ultrasonography were normal. On the second day of hospitalization, fever and refusal of feeding were resolved..Antiviral treatment was not given. After the first SARS-CoV-2 rRT-PCR test (Bio-speedy, Bioeksen, Istanbul, Turkey) result was positive, all his close contacts (his mother and grandmother) who had no symptoms or signs were screened for SARS-CoV-2 and revealed as positive. Blood culture and urine culture were negative. Antibiotic therapy was stopped on the seventh day of hospitalization. On the 7th and 9th days of his symptoms, a pharyngeal swab for SARS-CoV-2 rRT-PCR remained positive. His control laboratory results were as follows: hemoglobin: 12 $\mathrm{g} / \mathrm{dL}$, white blood cell count: $8.40 \times 10^{9} / \mathrm{L}$, lymphocyte count: $5.81 \times 10^{9} / \mathrm{L}$, neutrophil count: $1.28 \times 10^{\%} / \mathrm{L}$, platelet count: $231 \times 10^{3} / \mathrm{L}$, and C-reactive protein: $0.6 \mathrm{mg} / \mathrm{L}(0-5)$, alanine aminotransferase (ALT): $77 \mathrm{U} / \mathrm{L}$, aspartate aminotransferase (AST): $129 \mathrm{U} / \mathrm{L}$, albumin: $3.2 \mathrm{~g} / \mathrm{L}$, and total protein: $4.9 \mathrm{~g} / \mathrm{L}$; the other biochemical test results were within normal ranges. He was discharged from the hospital in good condition. He, his parents, and grandmother were quarantined for 14 days and monitored by daily phone calls. On the $14^{\text {th }}$ day of symptoms, the first negative SARS-CoV-2 rRT-PCR result was obtained. In addition, on the 21 st day of symptoms, all family members' and his SARS-CoV-2 rRT-PCR tests were negative.

\section{Discussion}

The COVID-19 disease affects all age groups, but most cases and death are seen in older adults. Child cases usually have milder symptoms and less severe disease than adults. Severe cases are commonly seen in patients under one year old, adolescents and patients who have an underlying chronic disease. In addition, asymptomatic infection is very common in children. The first pediatric case in China was reported in a family clustering, it was indicated that the family clustering might be caused by the spread of disease in children (7). Lu et al. revealed that among the children who had been diagnosed with COVID-19, the rate of having confirmed and suspected disease family members was respectively $76.6 \%$ and $13.5 \%$ (8). It was shown that children are at high risk for COVID-19 disease in the home when any family member has COVID-19 disease (9). In our case, his father had suffered mild weakness for two days before our case's symptoms began. After screening family members, it was revealed that all family members were positive even though they did not have any symptoms.

Although newborns are more vulnerable to infectious diseases because of their immature immune system, COVID-19 disease has a mild course in newborns. The most common clinical symptoms in the newborn are shortness of breath, vomiting, cough, and fever (10). Some of these symptoms were consistent with our case. Up to date, none of the newborns with COVID-19 was given any antiviral treatment, like our case. In our case, the first negative test result was revealed on the $14^{\text {th }}$ day of symptoms. In the literature, the negative conversion was seen in newborns between the $14^{\text {th }}$ and $15^{\text {th- }}$ day $(4,11,12)$. Besides, Cai et al. revealed that the median day of negative conversion was 12 days (range 6-22 days) in their ten-children case series (13).

In our case, we considered that close contact of family members was the main source of the transmission of the disease. The mother was asymptomatic, and we could not know if the mother got the infection while in pregnancy or the postpartum period. However, the fact that the baby was 17 days old when diagnosed suggests that he got the virus in the postnatal period. Therefore, we could not be clear about the terms of vertical transmission. The vertical transmission and transmission through breast milk of SARS-CoV-2 is not clear, and there have been several studies concerning the potential vertical transmission of SARS-CoV-2 and its effects on newborns (14-16). First reports have shown newborns born to SARS-CoV-2-infected mothers and all samples, including 
amniotic fluid, breast milk, and cord blood were negative for nucleic acid test for SARS-CoV-2 $(17,18)$. Current reports have shown early positives for nucleic acid test results for SARSCoV-2 in newborns with COVID-19 mother or positive immunoglobulin $M$ (IgM) levels (10). On the other hand, his father was a cabin crew member and recently had traveled abroad. The mother and grandmother had no contact history except for family members. The socioeconomic level of the family was good and there was no smoking history in the family. The mother had a healthy diet and vitamin supplements during pregnancy. Our patient did not have any health problems during the neonatal period and started feeding with breast milk immediately after birth. Family hand hygiene habits were observed to be good.

Hand and breast hygiene and wearing a facial mask should be encouraged for mothers during breastfeeding. Ideally, the infant is fed with the expressed breast milk of bottle-feeding by healthy caregivers using hand hygiene precautions and wearing a mask. Knowledge of the clinical course of the newborn with COVID-19 is still limited. During this very contagious outbreak, the COVID-19 disease should be considered in newborns with fever or refusal of feeding.

Informed Consent: Patient consent was obtained.

Peer-review: Externally peer-reviewed.

Author Contributions: Concept - GA, DB; Design - GA, BC, Supervision - DB, EA, Resources - GA, DK; Data collection and/or Processing - GA, DO, NK; Literature Review - GA, BC; Writing- GG, BC; Critical Review- EA, DB.

Conflict of Interest: No conflict of interest was declared by the authors.

Financial Disclosure: The authors declared that this study has received no financial support.

\section{References}

1. Dong $Y$, Mo $X, H u Y$, Qi $X$, Jiang $F$, Jiang $Z$ et al. Epidemiological characteristics of 2143 pediatric patients with 2019 Coronavirus Disease in China. Pediatrics 2020;145(6):e20200702. [CrossRef]

2. Wu Z, McGoogan JM. Characteristics of and important lessons from the coronavirus disease 2019 (COVID-19) outbreak in China: summary of a report of 72314 Cases From the Chinese Center for Disease Control and Prevention. JAMA 2020;323(13):1239-42. [CrossRef]
3. Ludvigsson JF. Systematic review of COVID-19 in children shows milder cases and a better prognosis than adults. Acta Paediatr 2020;109(6):1088-95. [CrossRef]

4. Wang S, Guo L, Chen L, Liu W, Cao Y, Zhang J, et al. A case report of neonatal COVID-19 infection in China. Clin Infect Dis 2020;71(15):8537. [CrossRef]

5. Kamali Aghdam M, Jafari N, Eftekhari K. Novel coronavirus in a 15-dayold neonate with clinical signs of sepsis, a case report. Infect Dis (Lond) 2020;52(6):427-9. [CrossRef]

6. Zhang ZJ, Yu XJ, Fu T, Liu Y, Jiang Y, Yang BX et al. Novel coronavirus infection in newborn babies under 28 days in China. Eur Respir $J$ 2020;55(6):2000697. [CrossRef]

7. Liu W, Zhang Q, Chen J, Xiang R, Song H, Shu S, et al. Detection of Covid-19 in children in early January 2020 in Wuhan, China. N Engl J Med 2020;382(14):1370-1. [CrossRef]

8. Lu X, Zhang L, Du H, Zhang J, Li YY, Qu J, et al. SARS-CoV-2 infection in children. N Engl J Med 2020;382(17):1663-5. [CrossRef]

9. Cao $Q$, Chen YC, Chen $C L$, Chiu CH. SARS-CoV-2 infection in children: Transmission dynamics and clinical characteristics. J Formos Med Assoc 2020;119(3):670-3. [CrossRef]

10. Zeng L, Xia S, Yuan W, Yan K, Xiao F, Shao J, et al. Neonatal earlyonset infection with SARS-CoV-2 in 33 neonates born to mothers with COVID-19 in Wuhan, China. JAMA Pediatr 2020;174(7):722-5. [CrossRef]

11. Zeng LK, Tao XW, Yuan WH, Wang J, Liu X, Liu ZS. First case of neonate with COVID-19 in China. Zhonghua Er Ke Za Zhi 2020;58(4):279-80. [CrossRef]

12. Choi SH, Kim HW, Kang JM, Kim DH, Cho EY. Epidemiology and clinical features of coronavirus disease 2019 in children. Clin Exp Pediatr 2020;63(4):125-32. [CrossRef]

13. Cai J, Xu J, Lin D, Yang Z, Xu L, Qu Z, et al. A Case Series of children with 2019 novel coronavirus infection: clinical and epidemiological features. Clin Infect Dis 2020;71(6):1547-51. [CrossRef]

14. Chen H, Guo J, Wang C, Luo F, YuX, Zhang W, et al. Clinical characteristics and intrauterine vertical transmission potential of COVID-19 infection in nine pregnant women: a retrospective review of medical records. Lancet 2020;395(10226):809-15. [CrossRef]

15. Li Y, Zhao R, Zheng S. Lack of vertical transmission of severe acute respiratory syndrome coronavirus 2, China. Emerg Infect Dis 2020;26(6). [CrossRef]

16. Li $Y$, Zhao $R$, Zheng $S$, Chen $X$, Wang J, Sheng $X$, et al. Clinical manifestations and outcome of SARS-CoV-2 infection during pregnancy. J Infect 2020. [CrossRef]

17. Chen Y, Peng H, Wang L, Zhao Y, Zeng L, Gao H, et al. Infants Born to Mothers With a New Coronavirus (COVID-19). Front Pediatr 2020;8:104. [CrossRef]

18. Zhu H, Wang L, Fang C, Peng S, Zhang L, Chang G, et al. Clinical analysis of 10 neonates born to mothers with 2019-nCoV pneumonia. Transl Pediatr 2020;9(1):51-60. [CrossRef] 